\title{
SMART DIGITAL AND ANALOGUE AMBIENCE CONTROL AND AUTOMATION USING ATMEGA 128 MICROCONTROLLER
}

\author{
Aarti Chauhan ${ }^{1}$, Ramandeep Singh ${ }^{2}$ \\ ${ }^{1} P G$ Student M.Tech (ES), EECE Department, ITM University, Gurgaon, Haryana, India \\ ${ }^{2}$ Assistant Professor, EECE Department, ITM University, Gurgaon, Haryana, India
}

\begin{abstract}
In day to day life we are becoming advance and with the advancement in technology we make things which are simple and easy. With this comes the concept of smart home systems which is preferred over manual system. Smart home plays a very vital role. Smart home is the advanced system technology to enable domestic task, communication and most importantly security. It is called smart home because it will inform the homeowners of any suspect in the home or about any problem so that they can investigate later. It also reduces our operating cost. This paper offers various features of smart home like security, gas sensors, temperature sensors etc.
\end{abstract}

Keywords: Smart Home, Automation, Ambience Control etc....

\section{INTRODUCTION}

Smart homes connect all the devices that use electricity and can be put on home network so that they can communicate with each other and with you [1]. As a human being we sometimes keep forgetting little things. What if mistakes are not to be mended? Many people sometimes forget that they have put something on a gas stove and without removing they move out of the house [2]. If it is a conventional home it will surely catches fire but if it is a smart home it will remind the homeowner every time before going out. Smart home system is comprised of three main technologies: advanced computer technology, network communication technology and automatic control technology [3]. In automation we use control systems and information technologies to reduce human work. Smart homes not only work smartly but also intelligently. It also tells how to manage the devices or appliances in home. This offers more satisfactory facilities with automatic control of devices [4].

\section{BLOCKDIAGRAM}

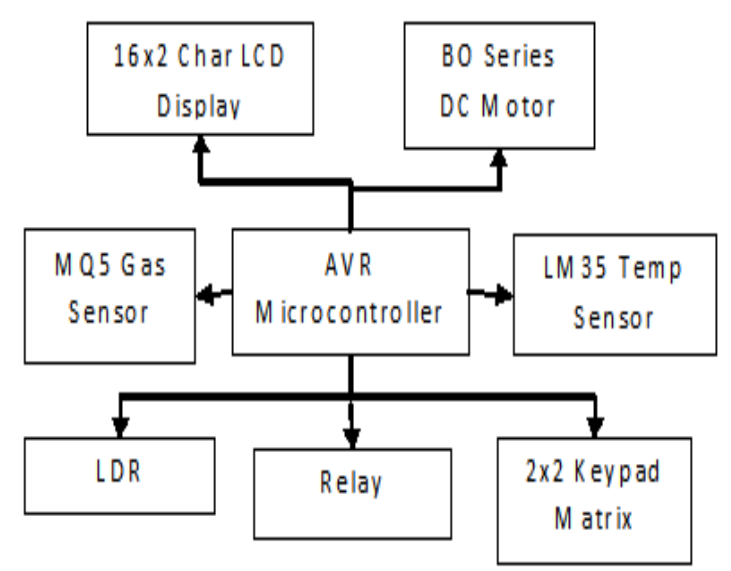

Fig 1: Block Diagram of Smart Home Automation
AVR microcontroller is the main controller of the system. It controls all the peripherals of the system. The MQ5 Gas Sensor senses the leakage of the LPG or any natural gas [5] [6]. The output of this sensor is 'high' at normal condition. The output goes low, when it senses the LPG. LDR (Light Dependent Resistor) is used to check sun light intensity; so that we can know it is day or night [7] [8]. LM35 Temp Sensor is used to measure room temperature and give it to microcontroller for desirable action [9] [10]. 16x2 Char LCD Display is used to display all sensors value and action taken by system on display. 2x2 Keypad Matrix is used for enter password to access the door. DC Motor is used for opening and closing the door.

\section{TYPES OF SENSORS}

Table 1: Types of Sensors

\begin{tabular}{|c|c|}
\hline $\begin{array}{ll}\text { LM35 } & \text { Temp } \\
\text { Sensor } & \end{array}$ & $\begin{array}{l}\text { LM35 series is a precision } \\
\text { centigrade temp sensor whose } \\
\text { output voltage is linearly } \\
\text { proportional to centigrade } \\
\text { temperature. Basic advantage } \\
\text { of LM35 over linear } \\
\text { temperature sensors is that to } \\
\text { obtain centigrade scaling there } \\
\text { is no need to subtract bigger } \\
\text { constant voltage from the } \\
\text { output. This sensor can draw } \\
\text { only } 60 \mu \mathrm{A} \text { from the supply. } \\
\text { Temperature range is from } \\
-55^{\circ} \mathrm{C} \text { to }+150^{\circ} \mathrm{C} \text {. }\end{array}$ \\
\hline LDR & $\begin{array}{l}\text { LDR is also known as photo } \\
\text { resistor, photo resistor, } \\
\text { photoconductor, } \\
\text { photoconductive cell, or simply } \\
\text { the photocell. LDR uses } \\
\text { photoconductor which is when } \\
\text { exposed to light a resistance }\end{array}$ \\
\hline
\end{tabular}




\begin{tabular}{|l|l|}
\hline & $\begin{array}{l}\text { change occurs. There are two } \\
\text { types of photo resistor: intrinsic } \\
\text { and extrinsic photo resistor. } \\
\text { LDR used here is OPR12 used } \\
\text { for general light sensing. }\end{array}$ \\
\hline $\begin{array}{l}\text { MQ5 Gas } \\
\text { MQ5 gas sensor is used to } \\
\text { determine any natural gas } \\
\text { which undergoes leakage. } \\
\text { Power requirements: 5Volts } \\
\text { operating temp range: }+32^{\circ} \mathrm{F} \text { to } \\
+158^{\circ} \mathrm{F}\left(0^{\circ} \mathrm{C} \text { to }+70^{\circ} \mathrm{C}\right)\end{array}$ \\
\hline
\end{tabular}

\section{FLOWCHART AND ALGORITHM}

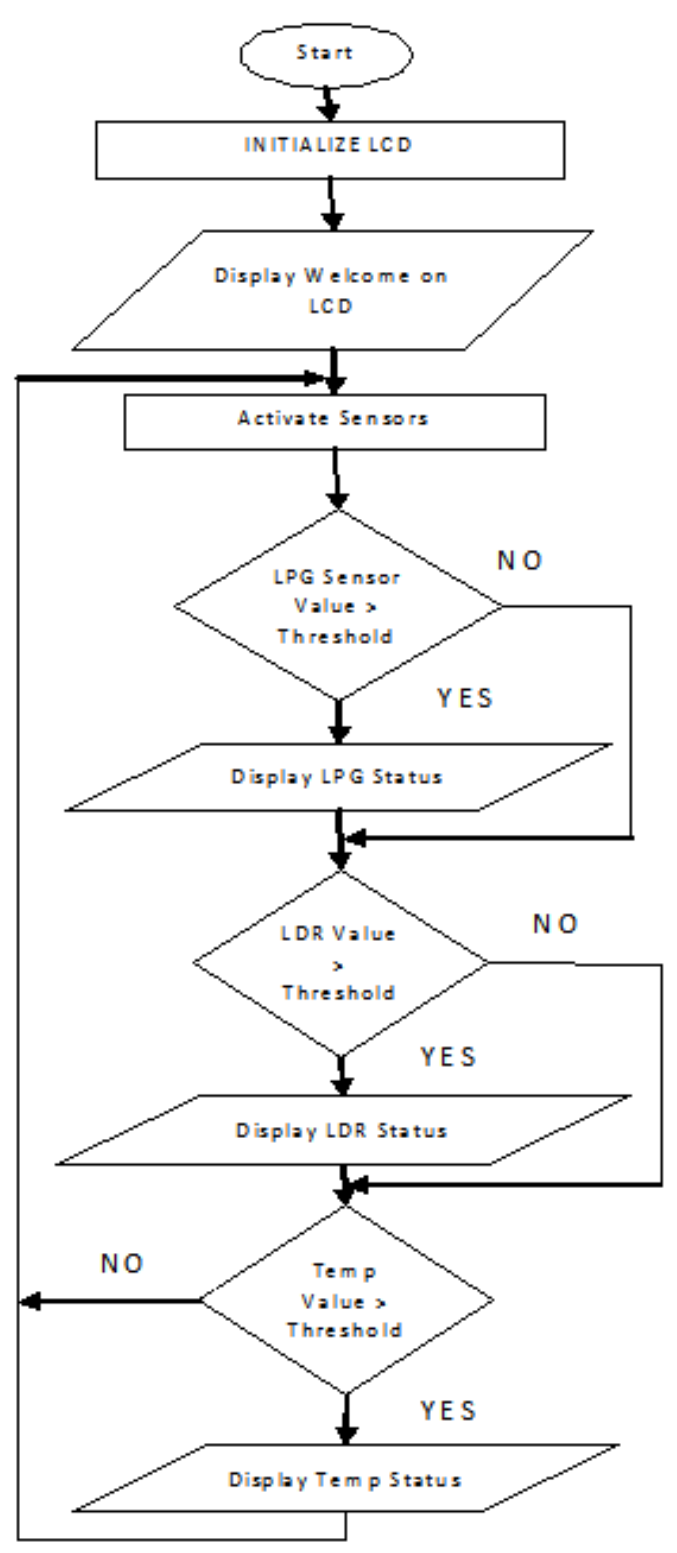

Fig 2: Flowchart and Algorithm

Three sensors are used. These are: MQ5 Gas Sensor, LM35 Temp Sensor and LDR (Light Dependent Resistor). All the sensor outputs are connected with in-built ADC of microcontroller to get digital value and rest of the interfacing of $2 \times 2$ keypad, DC Motor, LCD Display, buzzer, transistors and LEDs are connected with input/output pins of microcontroller.

When power is switched on, LCD is initialised and displays the welcome message "WELCOME TO SMART HOME". After this, LPG sensor is activated and will check if its value is greater than the threshold value or not. Every sensor has their threshold value and based on the sensors output all output devices act accordingly which are connected with the microcontroller. If the value is greater than the threshold value, it will display the status accordingly. If not, then will check the next sensor i.e LDR. Same it will check for the temp sensor. Every time sensors will compare their output values with the threshold values and if found greater than status will be displayed. BC548 NPN transistor is also interfaced with relay because any if any $\mathrm{AC}$ device has to be switched ON or OFF according to the sensor then relay will operate accordingly.

$2 \times 2$ Keypad matrix is also interfaced to access the opening and closing of the door after entering the desired password. When 'password' is entered by a user through keypad then the current password is compared with the password written in the source code. If the password is correct DC motor will rotate and the door is opened but if password is incorrect then buzzer will produce a sound and 'password incorrect' will be displayed on the LCD. So you have to try again.

\section{APPLICATION AREA}

Internet-connected video camera can check on the person at home while at work. You can operate your home lightening system without moving an inch. The whole-audio system creates the ambience you desire to lift up your mood or play tunes according to your mood. The home automation technology allows users to set their own climate. It will inform you if there is any gas leakage in the house by turning on the buzzer while you are at home or through email or message in your phone while away from home.

By sensing the temperature outside it will set the temperature inside home accordingly before the time you arrive. Want to see who is at the front door without leaving the comfort you can see through the display showing in your TV screen. Smart home security system will alert you through email or phone if it detects some activity while you are away. You can also program your security system to detect the difference between an animal and human walking. Smart Lighting Control. Control your lighting system when you are away or by sensing motion it will turn off or dim the lights when room is unoccupied. You can control your home automation security system from anywhere in the world and get alerts from smart home if sense any motion.

\section{ADVANTAGES \& LIMITATION}

Smart home automation systems are easy and simple to use. You don't need to programme your automation system. Once installed you just need to activate and enjoy the lifestyle. Smart home automation system improves safety 
and security by giving instant message once intruder is inside your property.

Your smart home will activate the lights before you reach home. If you forget things easily then smart home is the best technology you can opt. It can control lights, lock doors etc. Offers energy enhancement by shutting the lights automatically when no one is in the room.

Smart home automation is system is very expensive. So, mostly upper-class families can afford it. It is also very difficult to install. One time installation is not possible.

\section{CONCLUSIONS \& FUTURE SCOPE}

The main objective this paper is to design and implement the security system for the smart home and other type of smart home system like temperature sensing, gas leakage detection etc. This paper proposed a various application areas of a smart home and advantages of smart home automation system. The connectivity through internet is also a main stream of this paper.

Smart homes have lots of new technology that will someday be common place. Great ideas that are coming from smart homes are beneficial to all.

\section{ACKNOWLEDGEMENTS}

I take this opportunity to express my profound gratitude and deep regards to my professors, staff members of Department of Electrical, Electronics \& Communication Engineering of ITM University, Gurgaon and other faculties for their exemplary guidance throughout.

\section{REFERENCES}

[1]. Rosslin John Robles and Tai-hoon Kim "A Review on Security in Smart Home Development" International Journal of Advanced Science and Technology, Vol. 15, February, 2010

[2]. Meensika Sripan, Xuanxia Lin, Ponchan Petchlorlean and Mahasak Ketcham "Research and Thinking of Smart Home Technology" International Conference on Systems [3]. Ms. Chetana Sarode "Smart Home Implementation Techniques: A Survey Approach" International Journal of Science, Engineering and Technology Research (IJSETR) Volume 1, Issue 6, December 2012

[4]. Mohammad Arif Hossain, Md. Nazmul Hasan "Modern Home Automation System Based On AVR Microcontroller" International Journal of Scientific \& Engineering Research, Volume 5, Issue 1, January-2014

[5]. Jayashri Bangali and Arvind Shaligram "Design and Implementation of Security Systems for Smart Home based on GSM technology" International Journal of Smart Home, Vol.7, No.6 (2013)

[6]. Gowthami.T and Dr. Adiline macriga. G "Smart Home Monitoring and Controlling System Using Android Phone" International Journal of Emerging Technology and Advanced Engineering, Volume 3, Issue 11, November 2013
[7]. Sheikh Izzal Azid and Sushil Kumar "Analysis and Performance of a Low Cost SMS Based Home Security System" International Journal of Smart Home, Vol. 5, No. 3, July, 2011

[8]. Jayashri Bangali and Arvind Shaligram "Energy efficient Smart home based on Wireless Sensor Network using LabVIEW" American Journal of Engineering Research (AJER), Volume-02, Issue-12, 2013

[9]. Y.R.Dhumal and J.S.Chitode "Green House Automation using Zigbee and Smart Phone" International Journal of Advanced Research in Computer Science and Software Engineering, Volume3, Issue 5, May 2013

[10]. Dr. A.J. Patil, Rajesh R. Karhe and Mahesh S.Patil "Real Time System Development for Home Automation using LabVIEW" International Journal of Advances Research in Electrical, Electronics and Instrumentation Engineering, Vol. 2, Issue 4, April 2013 